\title{
Breeding Biology of King Eiders Nesting on Karrak Lake, Northwest Territories
}

\author{
DANA K. KELLETT ${ }^{1}$ and RAY T. ALISAUSKAS ${ }^{2}$
}

(Received 19 March 1996; accepted in revised form 18 November 1996)

\begin{abstract}
We studied various aspects of the breeding biology of king eiders (Somateria spectabilis) nesting at Karrak Lake, south of Queen Maud Gulf in the central Canadian Arctic. We found 41 nests distributed among 10 islands in Karrak Lake; to our knowledge, this represents the largest number of king eider nests studied at one site. We suspect that island nesting by king eiders is more common than has been previously reported. King eiders favoured mid-sized islands $\left(0.002-0.081 \mathrm{~km}^{2}\right)$ over very small (less than $0.002 \mathrm{~km}^{2}$ ) or very large (greater than $0.081 \mathrm{~km}^{2}$ ) islands. Mean clutch size was $5.4 \pm 1.7$ (SD) eggs. Apparent nest success was 69.4\%, with a composite Mayfield estimate of nest success over egg laying and incubation of $48.7 \%$ (95\% CI: 47.4$50.0 \%)$. Nest success was uncorrelated with date of nest initiation or island size, but eiders nesting on islands farther from the mainland had greater success than those nesting on islands closer to the mainland. Additionally, nest success was greater on islands with more nesting eiders and on islands with nesting arctic terns (Sterna paradisaea).
\end{abstract}

Key words: colonial nesting, habitat selection, king eider, Somateria spectabilis, nesting associations, nest success, Queen Maud Gulf Bird Sanctuary

RÉSUMÉ. On a étudié divers aspects de la biologie reproductive de l'eider à tête grise (Somateria spectabilis) nichant au lac Karrak, qui se trouve au sud du golfe de la Reine-Maud, au centre de l'Arctique canadien. On y a trouvé 41 nids répartis sur 10 îles situées dans le lac Karrak; à notre connaissance, cela représente le plus grand nombre de nids d'eiders à tête grise faisant l'objet d'une étude sur un seul site. On soupçonne que l'eider à tête grise niche plus couramment dans des îles qu'on ne l'avait rapporté précédemment. Les individus préféraient les îles de taille moyenne $\left(0,002\right.$ à $\left.0,081 \mathrm{~km}^{2}\right)$ aux îles très petites (moins de $\left.0,002 \mathrm{~km}^{2}\right)$ ou très grandes (plus de $0,081 \mathrm{~km}^{2}$ ). La taille moyenne des couvées était de 5,4 oeufs, avec un écart-type de 1,7. Le taux d'éclosion apparente était de 69,4 p.cent, avec une estimation composée de Mayfield de 48,7 p.cent (intervalle de confiance au seuil de 95 p.cent: 47,4 à 50,0 p.cent) pour le succès de la couvaison par rapport à celui de la ponte et de l'incubation. Le succès de la couvaison n'était pas corrélé à la date du début de la nidification ou à la taille de l'île, mais les eiders nichant sur les îles les plus éloignées du continent réussissaient mieux que ceux nichant sur les îles plus proches du continent. En outre, le succès de la nidification était plus grand sur les îles où nichaient plus d'eiders et sur celles où nichaient aussi des sternes arctiques (Sterna paradisaea).

Mots clés: nidification en colonies, sélection de l'habitat, eider à tête grise, Somateria spectabilis, associations de nidification, succès de la couvaison, refuge d'oiseaux du golfe de la Reine-Maud

Traduit pour la revue Arctic par Nésida Loyer.

\section{INTRODUCTION}

The king eider (Somateria spectabilis) is one of the most northerly nesting ducks (Palmer, 1977), seldom nesting below $65^{\circ} \mathrm{N}$ latitude (Lamothe, 1973). The species has a circumpolar breeding distribution and occurs in northern Russia, northern Alaska, Greenland, and arctic regions of Canada, including coastal mainland areas and most islands of the Arctic Archipelago (Johnsgard, 1975, 1978; Bellrose, 1976; Abraham and Finney, 1986; Barry, 1986 and references therein). The distance that king eiders travel inland to breed varies, being greatest in areas with many scattered ponds and lakes (Palmer, 1975). In Canada, king eiders usually were assumed to nest near freshwater lakes and streams, or on small islets along the coast (Bellrose, 1976), but occasionally they nest above the high tide lines of seacoasts (Johnsgard, 1975, 1978).

Typically thought to be solitary nesters, king eiders were regarded as being intolerant of other eiders nesting in close proximity (Palmer, 1975). However, there have been several reports of "semicolonial" nesting on islands in tundra lakes (Soper, 1928; Hanson et al., 1956; Manning et al., 1956). Dement'ev and Gladkov (1952) reported that king eiders shared small river islands with nesting geese and gulls.

Despite evidence for this species' great abundance (Thompson and Person, 1963; Bellrose, 1976; Woodby and Divoky, 1982; Abraham and Finney, 1986; Barry, 1986), its breeding ecology is not well known; we have very little information on nesting success. In this study, we examined the reproductive biology and ecology of king eiders nesting

\footnotetext{
${ }^{1}$ Box 88, Carrot River, Saskatchewan S0E 0L0, Canada; present address: Department of Biology, University of Saskatchewan, 112 Science Place, Saskatoon, Saskatchewan S7N 5E2, Canada

${ }^{2}$ Prairie and Northern Wildlife Research Centre, Canadian Wildlife Service, 115 Veterinary Road, Saskatoon, Saskatchewan S7N 0X4, Canada

(C) The Arctic Institute of North America
} 
on islands in Karrak Lake, a freshwater breeding area in the Queen Maud Gulf Bird Sanctuary.

\section{STUDY AREA}

Karrak Lake $\left(67^{\circ} 14^{\prime} \mathrm{N}, 100^{\circ} 14^{\prime} \mathrm{W}\right)$ is located about $60 \mathrm{~km}$ south of Queen Maud Gulf in the central Canadian Arctic. It supports the largest known colony of lesser snow geese (Chen caerulescens) and Ross' geese (Chen rossii) in the Queen Maud Gulf Bird Sanctuary: 494000 breeding geese in 1995 (R. Alisauskas, unpubl. data). The area consists mainly of rock outcrops, sedge meadows, and marshy areas interrupted by shallow tundra ponds (Slattery, 1994). Karrak Lake encompasses $15.77 \mathrm{~km}^{2}$. Its area includes $13.54 \mathrm{~km}^{2}$ of surface water and $2.23 \mathrm{~km}^{2}$ of various-sized islands. The islands of Karrak Lake are composed mainly of rock and gravel, and sparsely covered with low-lying vegetation. The lake has an average depth of approximately $1.2 \mathrm{~m}$ (Ryder, 1972a) and, like many of the region's shallow lakes, likely freezes to much of the bottom during winter. Water began collecting on the ice surface by 6 June 1995, and lake ice broke up sufficiently to allow boat travel by 12 June 1995 .

\section{METHODS}

All islands ( $\mathrm{n}=37)$, except the largest (Camp Island), were systematically searched at least once during the period from 17 June 1995 to 10 July 1995 (Fig. 1). Nests found during egg laying were revisited during incubation to determine final clutch size. Nests were marked with small coloured markers placed about $1.0 \mathrm{~m}$ from the bowl in a visible location. The length and width of each egg was measured, and eggs were numbered with an indelible marker. It was difficult to determine egg-laying sequence by shell staining; hence, eggs were not necessarily numbered in order of laying. Incubation stage was determined by candling (following Weller, 1956), and habitat type of 39 nests was determined by surveying the area immediately around each (less than a one metre radius), following the classification of McLandress (1983). The shortest distance from 37 nests to the lake shore was measured to the nearest $0.1 \mathrm{~m}$ with a measuring tape.

Nest initiation dates were calculated by back-dating from estimated incubation stage, assuming a laying interval of 1.0 day per egg (Lamothe, 1973). Hatch dates were determined from direct observation or from calculations from incubation stages.

Incubating females were captured by laying a mist net across them on the nest. Less frequently, spring nest traps were used, or eiders were flushed into mist nets. Captured eiders were marked with aluminum leg bands and weighed with a $3 \mathrm{~kg}$ spring scale, and morphometric measurements (Dzubin and Cooch, 1993) were recorded.

Nests were visited two to ten days after hatch to determine the fate of the eggs. Nests were considered successful if at least one egg hatched, as indicated by the presence of egg caps, unvascularized membranes, or small shell fragments.

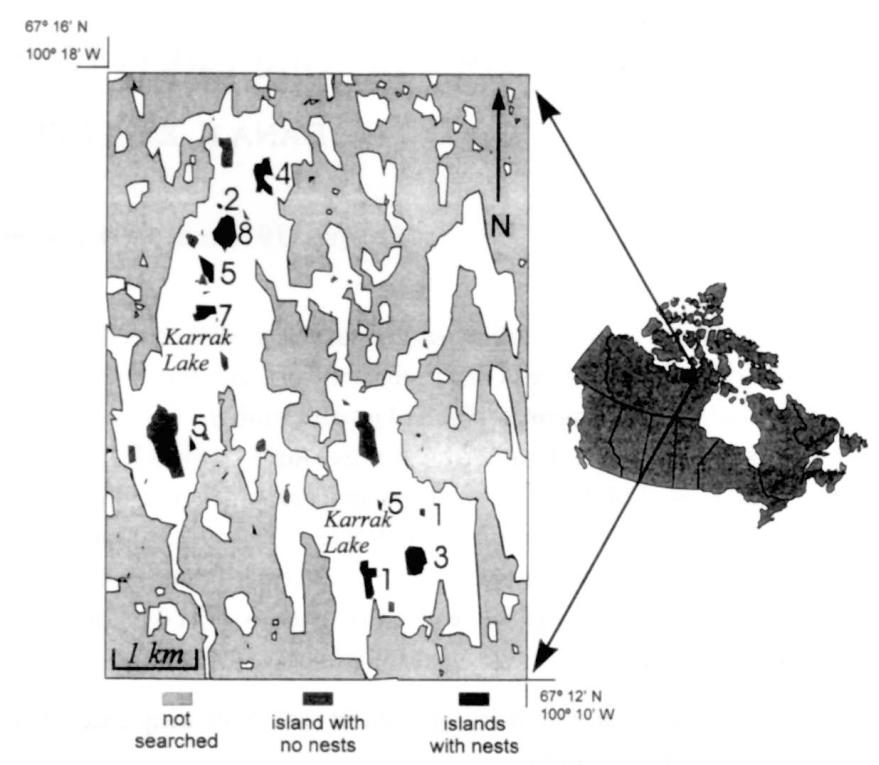

FIG. 1. Distribution of islands in Karrak Lake, N.W.T. Shown are islands that were not searched (same color as mainland, light grey); islands searched where no king eider nests were found (dark grey); and islands with nests (black, with number of nests indicated to the right of each island).

No nests were found with partially incubated, abandoned eggs, so we could not distinguish nests that were depredated from those that were abandoned. We calculated nest success using all nests found $(n=41)$, except those that were not found after initial location $(n=1)$, those suspected of abandonment due to nest trapping $(n=2)$, those abandonments apparently resulting from intraspecific egg dumping $(n=1)$, and those where it was unknown if predation occurred during laying or incubation $(\mathrm{n}=1)$.

The shoreline of the study area was digitized from 1:50 000 maps and imported into a geographical information system (GIS). This information was used to calculate areas of each island and Karrak Lake, and to measure minimum distances from each island to the mainland shore.

Apparent nest success is defined as the percentage of all nests found that were successful. Because this approach overestimates true nest success, we followed Mayfield (1975) to calculate nest success and Johnson (1979) to calculate approximate $95 \%$ confidence limits. To render results of other studies comparable to our Mayfield estimates, we followed Green (1989) and transformed published values of apparent nest success to Mayfield estimates.

We tested homogeneity of variances and equality of means for size of islands and their distance from the mainland shore of Karrak Lake for both islands that contained king eider nests and those that did not (PROC TTEST: SAS Institute Inc., 1990).

We used logistic regression (PROC PROBIT: SAS Institute Inc., 1990) to examine the relation of nest success $(n=36)$ to distance of the nesting island from the mainland, size of the nesting island, and date of nest initiation. We also analyzed nest success by expressing it as the number of successful nests divided by the total number of nests per island $\left(n_{\text {island }}=10\right)$ in relation to island distance from the mainland and number of king eider nests per island. 


\section{RESULTS}

\section{Numbers of Birds Present and Nest Initiation}

King eiders were first observed in the study area on 9 June 1995 , shortly after open water appeared on the ice surface. Two occurrences of groups of birds were seen at Karrak Lake (Fig. 2); the first, 9-28 June 1995 (peak 16 June 1995), and the second, 28 June 1995-10 July 1995 (peak 1 July 1995). On approximately 29 June 1995, large groups of males, consisting of up to 25 individuals, were observed at the north end of the lake. Males were not seen in the area after 6 July 1995.

Nest initiation began in mid-June and continued until early July (Fig. 2). The chronology of nest initiation did not exhibit the clear bimodality seen in the numbers of birds present on the study area.

\section{Habitat Use}

Location: Forty-one nests were found on 10 of 37 islands that were searched on Karrak Lake (Fig. 1). Although mean size of islands with nests (mean \pm 1 SD: $0.034 \pm 0.030 \mathrm{~km}^{2}$ ) and those without $\left(0.070 \pm 0.273 \mathrm{~km}^{2}\right)$ was not different $(t=$ 0.68 corrected for unequal variances, $\mathrm{df}=27.6, p=0.50$ ), the variance in size of islands with nests was considerably smaller than that for islands without nests $(F=83.0$, df $=26,9$; $p<0.0001$; Fig. 3). King eiders avoided the smallest islands (less than $0.002 \mathrm{~km}^{2}, \mathrm{n}=10,0 \%$ occupancy), chose to nest on medium-sized islands $\left(0.002-0.081 \mathrm{~km}^{2}, \mathrm{n}=24,42 \%\right.$ occupancy), and tended to avoid the largest islands (greater than $0.10 \mathrm{~km}^{2}, \mathrm{n}=3,0 \%$ occupancy; Figs. 1, 3). There were no differences in either the means $(t=-0.66, \mathrm{df}=35, p=0.55)$ or variances $(F=1.46, \mathrm{df}=26,9 ; p=0.57)$ in the distance of islands from the mainland between occupied $(184 \pm 177 \mathrm{~m})$ and unoccupied islands (222 \pm 147 m; Figs. 1, 3).

Distances from nests to water ranged from 5.8 to $62.0 \mathrm{~m}$ (24.1 $\pm 12.1 \mathrm{~m}, \mathrm{n}=37)$. As a result, nests were concentrated around the perimeters of the medium-sized islands but were more evenly distributed on the smaller islands.

Habitat: Eiders did not nest on islands consisting of bare rock, but were found on islands with some vegetation. Thirtyeight percent of nests $(n=39$; habitat not recorded for two nests) were in microhabitats of moss or "heath," primarily Labrador tea (Ledum decumbens) crowberry (Empetrum nigrum) and bearberry (Arctostaphylos spp.). Another $21 \%$ were in birch (Betula glandulosa). The rest were found in microhabitats of rock or gravel with no vegetation. Distribution and availability of habitat were not measured, so we were not able to determine if selection of particular habitats occurred for nest placement.

\section{Clutch and Egg Size}

The number of eggs found per nest ranged from two to ten, although there were no nests with seven eggs (Fig. 4). This bimodal distribution of clutch size may suggest that clutch sizes of eight or more eggs may have been laid by more than

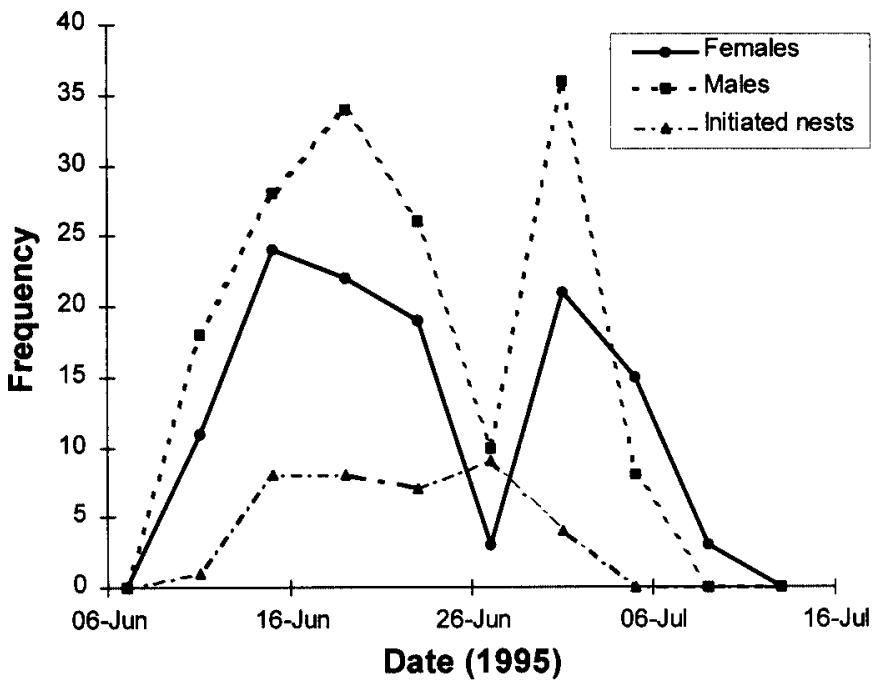

FIG. 2. Chronology of observations of male and female king eiders and nest initiation dates at Karrak Lake, N.W.T., 1995.

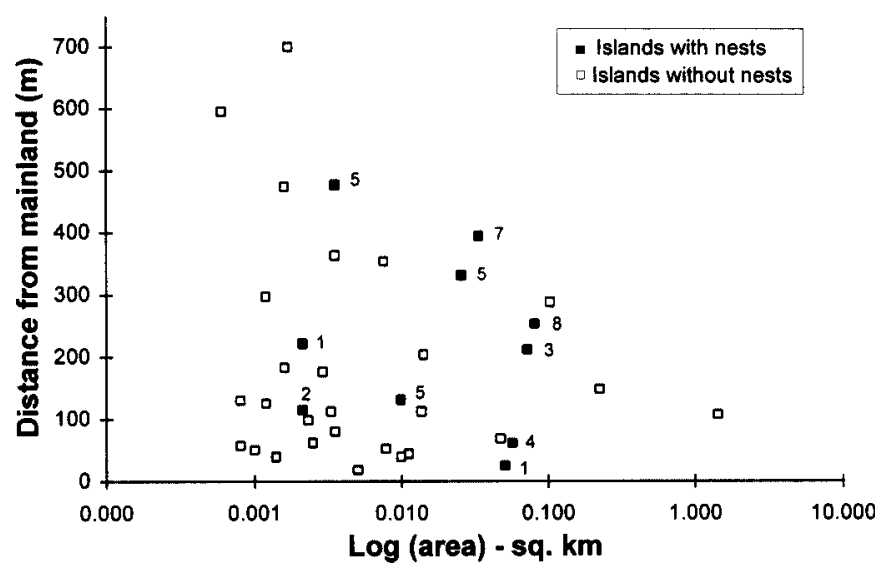

FIG. 3. Spatial characteristics of islands in Karrak Lake, N.W.T., with and without nesting king eiders (numbers indicate number of nests per island).

one female. Additionally, larger clutches were found earlier in the nesting season. If this assumption is correct, then $16.2 \%$ of nests were parasitized intraspecifically. King eider nests never contained eggs of other species, suggesting that interspecific parasitism does not readily occur in this population. Including clutches of eight or more eggs, mean clutch size was $5.4 \pm 1.7$ eggs $(n=37)$. Most nests were found during incubation, and so mean clutch size may be underestimated, since partial clutch loss to predators may have occurred before nests were found. Clutch size declined significantly during the nesting season $\left(r^{2}=0.48, \mathrm{n}=37, p<0.001, y=\right.$ $7565.56-0.22 x$; Fig. 5). Mean length of eggs was $66.6 \pm 2.7$ $\mathrm{mm}$, and mean width was $44.6 \pm 1.3 \mathrm{~mm}(\mathrm{n}=209)$.

\section{Incubation}

We estimated that incubation time ranged from 22 to 24 days. However, no nests were followed from laying of the first egg. Consequently, initiation date was calculated by 


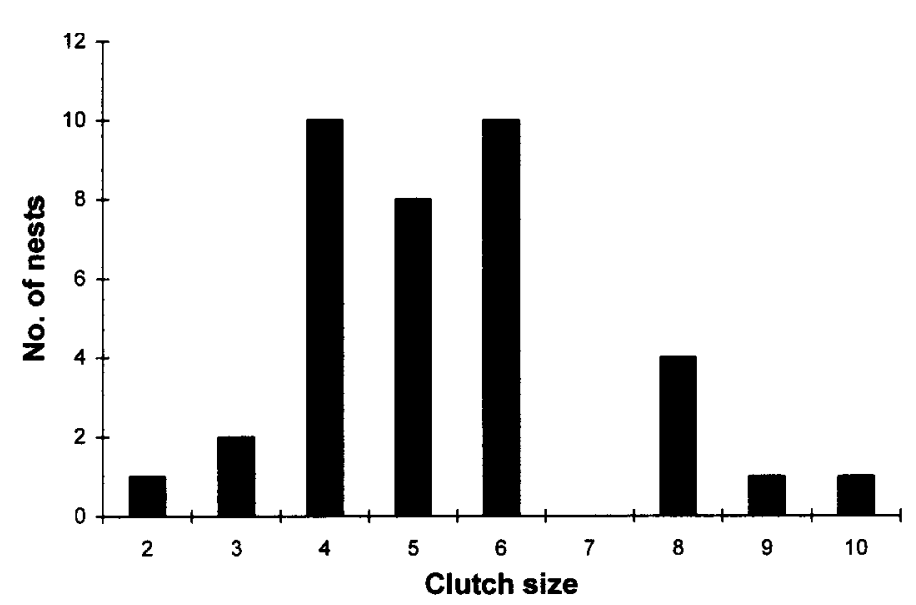

FIG. 4. Frequency distribution of king eider clutch sizes at Karrak Lake, N.W.T. $(\mathrm{n}=37)$.

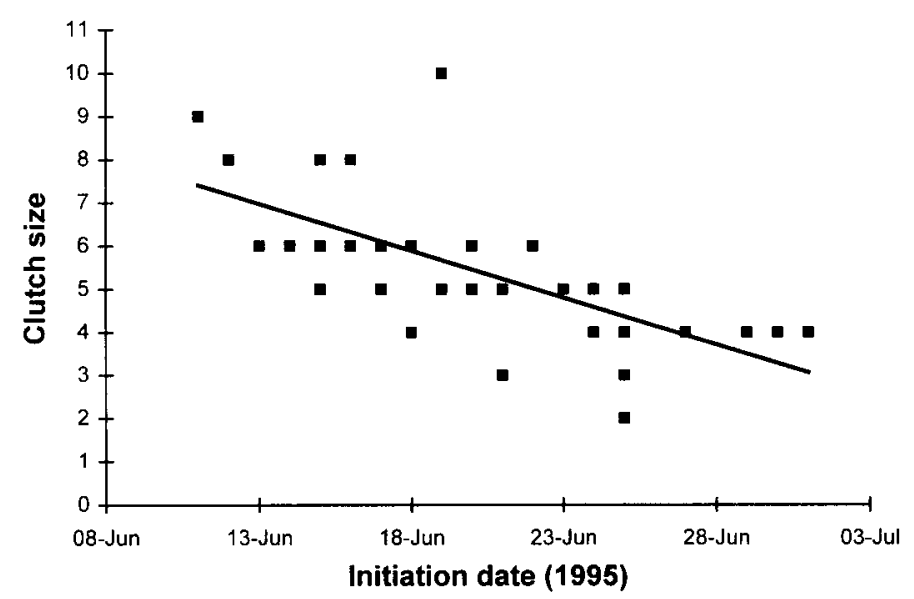

FIG. 5. Seasonal decline in clutch size of king eiders at Karrak Lake, N.W.T. $\left(y=7565.56-0.22 x, r^{2}=0.48, \mathrm{n}=37, p<0.001\right)$.

back-dating from incubation stages that we determined by candling eggs.

During incubation, females were captured easily because they tended to allow approach to within two metres before flushing from nests. During our approach, hens remained flattened and inconspicuous on their nests, often not flushing until touched by the net. When forced from the nest, females usually defecated on eggs and down. Table 1 contains morphological measurements of female king eiders captured during incubation.

Female mass declined significantly $\left(r^{2}=0.31, \mathrm{n}=25, p=\right.$ $0.004, y=1524.5-14.8 x$; Fig. 6$)$ through incubation. No females were captured before their twelfth day of incubation. If constant mass loss through incubation is assumed, then we estimate that females weighed $1.52 \mathrm{~kg}$ after clutch completion and $1.16 \mathrm{~kg}$ at hatch, representing a $24 \%$ loss of body weight during incubation.

\section{Hatch and Nesting Success}

Mean hatch date was 19 July 1995 . Apparent nest success was $69.4 \%$, based on 36 nests of known fate. Most nests were not observed throughout the entire nesting period, so we
TABLE 1. Morphological measurements (mean $\pm 1 \mathrm{SD}$ ) of female king eiders $(n=25)$ nesting at Karrak Lake, taken after 12-24 days of incubation.

\begin{tabular}{lr}
\hline \hline Measurement & Mean \pm 1 SD \\
\hline Culmen 1 (mm) & $32.7 \pm 2.0$ \\
Culmen 2 (mm) & $55.7 \pm 1.9$ \\
Head length $(\mathrm{mm})$ & $105.5 \pm 1.8$ \\
Head width $(\mathrm{mm})$ & $34.0 \pm 2.1$ \\
Skull height $(\mathrm{mm})$ & $40.0 \pm 1.3$ \\
Tarsus (bone, $\mathrm{mm})$ & $47.0 \pm 2.7$ \\
Wing chord $(\mathrm{mm})$ & $274.8 \pm 5.3$ \\
Mass $(\mathrm{g})$ & $1228.2 \pm 9.0$ \\
\hline \hline
\end{tabular}

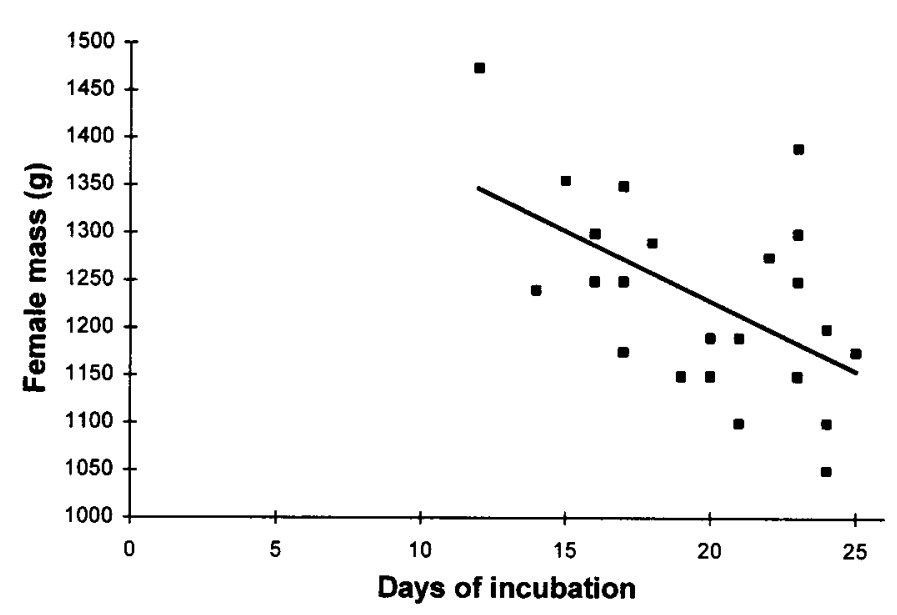

FIG. 6. Decline of female king eider mass during incubation $\left(y=1524.5-14.8 x, r^{2}=0.31, \mathrm{n}=25, p=0.004\right)$.

followed Mayfield's (1975) approach to account for incomplete observations. The cumulative number of observation days for six nests found during laying was 17 observation days, during which one nest was lost; therefore, daily nest survival was $1-(1 / 17)=0.9412$. This quotient raised to a power equivalent to the number of days of exposure (using clutch size of 5.4) yields a Mayfield (1975) estimate of nest survival during egg laying of $72.1 \%$ (95\% confidence interval [CI]: 69.6-74.6\%). During incubation, there were 592 cumulative observation days for 35 nests, during which 10 nests were destroyed; using incubation length of 23 days of risk as the exponent yields $(1-(10 / 592))^{23}=67.6 \%(95 \% \mathrm{CI}$ : $67.5-67.7 \%$ ) nest success during incubation. The product of success expressed as proportions during laying and incubation yields a composite estimate of $48.7 \%$ (95\% CI: $47.4-$ $50.0 \%$ ) during an average of 28.4 days of nesting. Three of the eleven failed nests were destroyed by avian predators, perhaps by glaucous gulls (Larus hyperboreus) and herring gulls (L. argentatus) or jaegars (Stercorarius spp.). Eight failed nests contained no egg shells or evidence of avian predation.

Nest success was unrelated to nest initiation date $\left(\chi^{2}=0.13\right.$, $\mathrm{df}=1, p=0.72)$. King eiders nesting on islands $\left(\mathrm{n}_{\text {islands }}=2\right)$ with nesting arctic terns (Sterna paradisaea) were more successful $(91.7 \%, \mathrm{n}=12)$ than those nesting on islands without terns $\left(48.2 \%, \mathrm{n}=27 ; \chi^{2}=6.21, \mathrm{df}=1, p=0.01\right.$, Fig. 7). Also, eider nests on islands farther from the mainland 


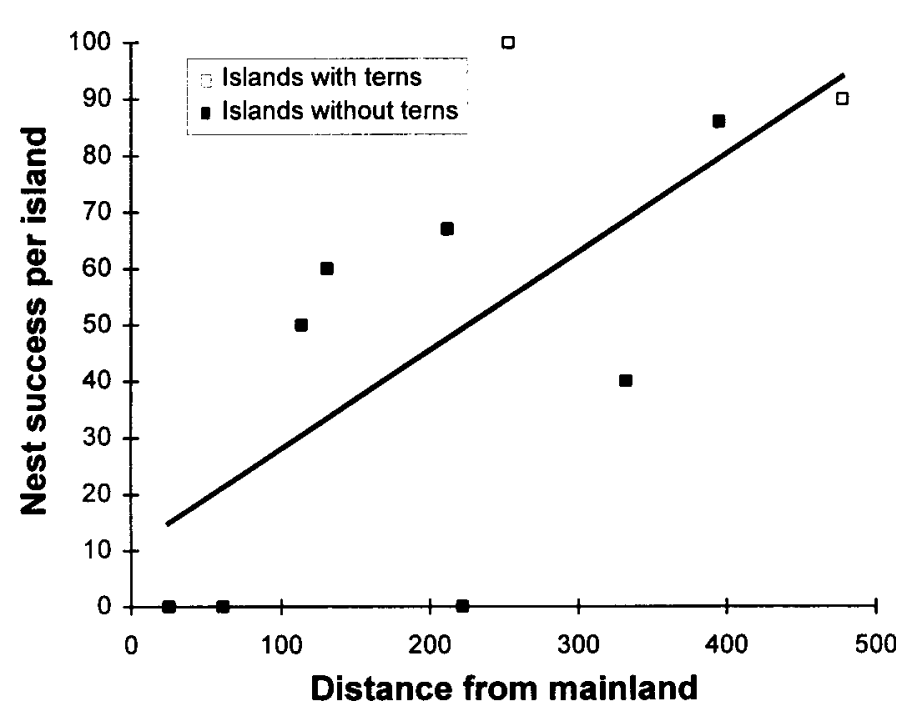

FIG. 7. Nest success per island of king eiders in relation to presence and absence of arctic terns, and to distance from mainland.

had greater nest success than those on islands nearer the mainland $\left(\chi^{2}=5.32\right.$, $\left.\mathrm{df}=1, p=0.02\right)$. Nest success was unrelated to island size $\left(\chi^{2}=0.73\right.$, df $\left.=1, p=0.39\right)$. Nest success per island was correlated with the number of eider nests per island $\left(r=0.77, \mathrm{n}_{\text {islands }}=10, p=0.01\right)$, and with the distance of the island from the mainland $\left(r=0.66, \mathrm{n}_{\text {islands }}=10\right.$, $p=0.04$, Fig. 7). This last relationship is strengthened by the inclusion of islands with terns in the analysis; islands with terns tended to be among the farthest from the mainland that also harboured eider nests (Fig. 7).

\section{DISCUSSION}

\section{Arrival and Nest Initiation}

King eiders usually are reported to be paired upon reaching the breeding grounds (Lamothe, 1973; Palmer, 1977; Johnsgard, 1978), although Johnson and Herter (1989) claimed that in some years, almost half of the eiders were not paired upon arrival. We observed copulation once on the study site in 1995, and females were often accompanied by more than one male. King eider males reportedly accompany the female until early incubation, and then congregate in groups to prepare for moult migration (Lamothe, 1973; Palmer, 1975, 1977). However, the length of associations between males and females after the onset of incubation is variable. Bray (1943) reported that males stay with females for some time after laying of eggs. Further, Hanson et al. (1956) believed that males remain with females for at least the first week of incubation, while Manning et al. (1956) reported that males left females once incubation began. At Karrak Lake, few males were present a week after most females began incubation (Fig. 2).

Baillie and Milne (1982) found that young common eiders (Somateria mollissima) began incubation later than older females, although the difference was not significant. The second peak of arrival and possibly nest initiation by king eiders that we observed at Karrak Lake may have resulted from an influx of younger birds. Unfortunately, we are unaware of a reliable aging technique for female king eiders, and consequently this hypothesis remains untested.

\section{Habitat Use}

Most of the occupied islands were small or medium-sized and composed of rock and gravel with some vegetation. Many of the small islands are bare rock outcrops or are submerged until late in the season and therefore not available for nesting. The largest islands may be perceived by females prospecting for nest sites as mainland areas, which provide no barriers against terrestrial predators-largely arctic fox (Alopex lagopus), but also wolves (Canis lupus), grizzly bears (Ursus horribilis) and wolverines (Gulo luscus). In fact, the largest island was known to contain two fox dens in 1994 (J. Bantle, pers. comm. 1995).

Females generally cover the eggs with vegetation upon leaving the nest during laying (Parmelee et al., 1967; Lamothe, 1973; Palmer, 1977). The presence of vegetation at nest sites may be important for this purpose. Nesting habitat reported by other authors is variable, from bare slopes (MacDonald, 1954; Parmelee et al., 1967; Bellrose, 1976) to well-vegetated areas (Manning and Macpherson, 1961; Bent, 1962).

King eiders nesting on the islands of Karrak Lake shared them with other nesting birds, including lesser snow and Ross' geese, glaucous and herring gulls, arctic terns, and long-tailed ducks (Clangula hyemalis). The proximity of king eider nests to water may not be due to a specific requirement. Parmelee et al. (1967) found 25 nests on dry, rocky slopes on Victoria Island, none of which were near water. Additionally, Manning and Macpherson (1961) reported nests located on dry, grassy tundra well away from water. The islands of Karrak Lake are first occupied by nesting Ross' and lesser snow geese (mean nest initiation was 10 June 1995; R. Alisauskas, unpubl. data), which occupy higher areas free of snow and water. Water levels fluctuate drastically in the spring; meltwater can raise the lake level as much as one metre (D. Kellett, pers. obs. 1995). By mid-June, when eiders began nesting, water levels had subsided, making available new nesting territory around the perimeter of the islands and uncovering other areas previously submerged. The availability of new territory, together with competition with nesting geese, may be responsible for eiders' selecting nest sites near water.

In at least three separate cases, we observed two or more females nesting within one metre of each other. This pattern has been noted occasionally for king eiders elsewhere (Parmelee et al., 1967; Abraham and Finney, 1986) and in other duck species as well (M. Gloutney, pers. comm. 1995); clustered nests may consist of closely related birds (Schmutz et al., 1983). Eiders nesting on islands with conspecifics had greater nest success than eiders nesting on islands with few females. We observed king eiders effectively defend nests against gulls during incubation. A female may choose to nest 
beside a laying or incubating female if the neighbouring female will defend the area from predators.

Habitat selection by eiders nesting at Karrak Lake may be motivated by avoidance of areas accessible to terrestrial predators. For example, Larson (1960) showed that selection of nest sites by king eiders may be directly related to predation pressure of arctic fox, glaucous gulls, and common ravens (Corvus corax). A number of studies mention the use of small islands as nesting sites by king eiders (Dement'ev and Gladkov, 1952; Hanson et al., 1956; Manning et al., 1956; Cramp and Simmons, 1977). Ryder (1972b) proposed that lesser snow geese and Ross' geese characteristically nest on islands of shallow lakes to avoid arctic fox predation.

On a larger scale, island nesting by king eiders may be more common in the Queen Maud Gulf Bird Sanctuary region than elsewhere. Hanson et al. (1956) found $19 \mathrm{king}$ eider nests on two islands on Discovery Lake, near the Perry River. Although eiders nest in other habitats, greatest densities are on islands in freshwater lakes. In 1991 and 1992, a systematic search of $24 \mathrm{~km}^{2}$ that contained water, but no islands in lakes, found only two king eider nests. The area searched was in the Queen Maud Gulf Bird Sanctuary near the Perry River, 70 to $140 \mathrm{~km}$ northwest of Karrak Lake (R. Alisauskas, unpubl. data). At Karrak Lake, 41 nests were found in $15.8 \mathrm{~km}^{2}$ of Sanctuary (composed of the lake and all islands). Previous researchers may have underestimated the frequency of high nesting densities of king eiders associated with islands in freshwater lakes because it was difficult to visit those islands.

\section{Clutch Size}

The suggestion that clutches of eight or more eggs are produced by more than one female has been made by others (Bailey, 1948; Hanson et al., 1956; Cramp and Simmons, 1977). Perhaps this possibility was not considered by Krapu and Reinecke (1992); they suggested that apparently large clutch sizes of king, spectacled (Somateria fischeri) and Steller's eiders (Polysticta stelleri) are a result of being less dependent on nutrient reserves for egg formation than common eiders. Nutrient reserves are important to nesting king eiders during incubation (see below), and we suggest that further study is required to confirm their suspected importance during egg laying.

In waterfowl, a seasonal decline in clutch size is a general phenomenon(Cooch, 1958; Barry, 1962, 1967; Ryder, 1972b). Several hypotheses have been proposed to explain this pattern. King eiders may rely on nutrient reserves, which decline seasonally, for egg formation (Alisauskas and Ankney, 1992). Barry (1962) suggested that smaller clutches late in the season were adaptive, in that they may enable late-nesting females to raise a smaller brood in a shorter time. Seasonal decline in clutch size also may be due to younger birds nesting later and laying smaller clutches (Dau, 1976). Possibly smaller clutches later may be an artifact of females that lay the first eggs of their clutch parasitically, but complete their clutch in their own nests (Ryder, 1972b).

\section{Incubation}

Incubation length for king eiders, as determined herein, is comparable with that of the common eider, which is about 26 days (Bellrose, 1976). Incubation length at Karrak Lake was similar to that cited for king eiders by Parmelee et al. (1967): 22-24 days.

\section{Nesting Success}

There is very little information on nesting success for the king eider. Nest success on Banks Island was 100\% (Mayfield: 100\%, following Green, 1989) in 1992 and $1993(\mathrm{n}=2,4$, respectively), while on Victoria Island three of five nests hatched in 1992 (Mayfield: 38\%) (L. Dickson, pers. comm. 1995). Nest success on Bathurst Island ranged between 0 and 22\% (Mayfield: 0-8\%) from 1968 to 1972 (Lamothe, 1973), although sample sizes were small (3-14 nests per year). Arctic fox were observed to be a substantial predator of eider eggs on Bathurst Island as well. The higher nest success at Karrak Lake (Mayfield: 48.7\%) compared to Bathurst Island may arise because of decreased predation rates of arctic fox resulting from island nesting.

Nest failure at Karrak Lake likely resulted from abandonment or predation by avian predators and possibly arctic fox. Almost all islands (approximately 90\%) with eiders nesting on them also had at least one pair of nesting gulls. However, of 117 eggshell remains found in glaucous gull pellets at Karrak Lake in 1994, only one was that of a king eider (G. Samelius and R. Alisauskas, unpubl. data). Jaegers were also present at Karrak Lake, and may have been a significant predator of eider eggs. Arctic fox are known to swim for short distances (Quinlan and Lehnhausen, 1982), and some eggs may have been taken by fox, particularly early in the nesting season when ice connected the islands to the mainland. The fact that nests on islands closer to the mainland were less successful than those further away supports this idea.

\section{Nesting Associations}

Many species of ducks have been observed to nest in association with colonial or solitary nesting birds (e.g., Blomqvist and Elander, 1988), usually gulls and terns. King eiders, in particular, are reported to have increased nesting success as a result of the anti-predator defense of the host (Lamothe, 1973; Summers et al., 1994). A number of nesting associations may be present at Karrak Lake, with both colonial and solitary breeding species.

Incubating geese were present on the islands during the laying and early incubation periods of the eiders. Individual lesser snow geese and Ross' geese are often able to deter nest predation by gulls and arctic fox (D. Kellett, pers. obs. 1995), although arctic fox appear to be the major nest predator of mainland-nesting geese at Karrak Lake. Common eiders nesting on islands with lesser snow geese tended to have greater hatching success than did those nesting on islands without geese at La Perouse Bay (Robertson, 1995). King 
eiders may benefit from the presence of the geese at Karrak Lake, notably during the laying period when the females are not constantly at the nest.

Arctic terns at Karrak Lake were extremely defensive of nesting areas, and were observed to chase away gulls and jaegers. It appears that king eiders nesting on islands with nesting arctic terns have greater nesting success than those nesting on islands without terns. This phenomenon has been reported for other waterfowl species as well (Evans, 1970; Young and Titman, 1986).

Nesting gulls were present on almost all islands with eiders. When geese are present, eiders may benefit from the mobbing defense of gulls against other gulls, jaegers, and arctic fox during laying and early incubation. After geese leave the area and young gulls hatch, eiders may experience an increased predation pressure due to the increased demand for food by the gulls and the absence of food that had been partly supplied by the geese. Bourget (1973) observed that black-backed gull (Larus marinus) predation on common eiders increased during the last half of incubation and at hatching time of the gulls' own eggs. Although eiders may benefit from aggressive behaviour of gulls early during nesting, gulls are a significant predator of waterfowl eggs and young at Karrak Lake. The costs and benefits of king eiders' nesting near gulls have not yet been determined.

\section{Mass Loss During Incubation}

Our estimate of $24 \%$ mass loss during incubation by king eiders is less than that reported for common eider (33\%) or lesser snow geese (32\%), is similar to values (range: $21-$ $27 \%$ ) for various races of Canada geese (Branta canadensis), and exceeds the range (11-20\%) for dabbling ducks (summarized by Afton and Paulus, 1992). However, our estimate of mass loss during incubation for king eiders does not appear to deviate from that observed in other waterfowl, when adjusted for body size (Afton and Paulus, 1992). Like most other large-bodied or arctic-nesting waterfowl, king eiders appear to rely on nutrient reserves during incubation.

\section{CONCLUSIONS}

Most previous studies on the nesting biology of king eiders have been plagued by small sample sizes because they examined dispersed nests, leading to the general belief that king eiders typically are dispersed nesters. We suggest that south of Queen Maud Gulf, where lakes with islands are abundant, island nesting by king eiders may occur frequently, or more often than dispersed nesting on mainland areas. Studies of island-nesting king eiders are not only logistically efficient, but could yield results representative of the nesting population over a larger regional scale.

There is a dearth of information about many ecological aspects of the annual cycle of king eiders. In Canada, in particular, the most pressing needs for effective management of king eiders are systematic inventory of numbers and distribution, and banding studies that could establish links between breeding and winter areas and provide information on survival rates (Abraham and Finney, 1986). Studies of annual survival relying on capture-mark-recapture methods (Lebreton et al., 1992) that lead to robust conclusions for king eiders may, in practice, only be feasible by studying dense nesting aggregations of females.

\section{ACKNOWLEDGEMENTS}

We thank J.L. Bantle, J.R. Danielson, M.L. Gloutney, S.L. Koch, T. Lau, E.L. MacHattie, and G. Mack for assistance in the field. Support for this study was provided by Canadian Wildlife Service and Polar Continental Shelf Project. R.G. Clark, L. Dickson, and M.L. Gloutney commented on an earlier draft of the manuscript. Comments from journal reviewers M. Elander, R. Suydam, and an anonymous reviewer are greatly appreciated.

\section{REFERENCES}

ABRAHAM, K.F., and FINNEY, G.H. 1986. Eiders of the eastern Canadian Arctic. In: Reed, A., ed. Eider ducks in Canada. Canadian Wildlife Report Series No. 47. 55-73.

AFTON, A.D., and PAULUS, S.L. 1992. Incubation and brood care. In: Batt, B.D.J., Afton, A.D., Anderson, M.G., Ankney, C.D., Johnson, D.H., Kadlec, J.A., and Krapu, G.L., eds. Ecology and management of breeding waterfowl. Minneapolis: University of Minnesota. 62-108.

ALISAUSKAS, R.T., and ANKNEY, C.D. 1992. The cost of egg laying and its relationship to nutrient reserves in waterfowl. In: Batt, B.D.J., Afton, A.D., Anderson, M.G., Ankney, C.D., Johnson, D.H., Kadlec, J.A., and Krapu, G.L., eds. Ecology and management of breeding waterfowl. Minneapolis: University of Minnesota. 30-61.

BAILEY, A.M. 1948. Birds of Arctic Alaska. Colorado Museum of Natural History Population Series No. 8. 317 p.

BAILLIE, S.R., and MILNE, H. 1982. The influence of female age on breeding in the eider Somateria mollissima. Bird Study 29:55-66.

BARRY, T.W. 1962. Effect of late seasons on Atlantic brant reproduction. Journal of Wildlife Management 26(1):19-26.

. 1967. Geese of the Anderson River Delta, N.W.T. Ph.D. Thesis, University of Alberta, Edmonton, Alberta. 212 p.

. 1986. Eiders of the western Canadian Arctic. In: Reed, A., ed. Eider ducks in Canada. Canadian Wildlife Report Series No. 47. 74-80.

BELLROSE, F.C. 1976. Ducks, geese, and swans of North America. 2nd ed. Harrisburg: Stackpole Books.

BENT, A.C. 1962. Life histories of North American wild fowl, Part II. New York: Dover Publications, Inc. 337 p.

BLOMQVIST, S., and ELANDER, M. 1988. King eider (Somateria spectabilis) nesting in association with long-tailed skua (Stercorarius longicaudus). Arctic 41(2):138-142. 
BOURGET, A.A. 1973. Relation of eiders and gulls nesting in mixed colonies in Penobscot Bay, Maine. Auk 90:809-820.

BRAY, R. 1943. Notes on the birds of Southampton Island, Baffin Island and Melville Peninsula. Auk 60:504-536.

COOCH, F.G. 1958. The breeding biology and management of the blue goose (Chen caerulescens). Unpubl. Ph.D. Thesis, Cornell University, Ithaca, New York.

CRAMP, S., and SIMMONS, K.E.L. 1977. Handbook of the birds of Europe, the Middle East, and North America: The birds of the Western Palearctic, Vol. 1, ostrich to ducks. Oxford: Oxford University Press.

DAU, C.P. 1976. Clutch sizes of the spectacled eider on the YukonKuskokwim Delta, Alaska. Wildfowl 27:111-113.

DEMENT'EV, G.P., and GLADKOV, N.A. 1952. Birds of the Soviet Union. Israel Program for Scientific Translation, Jerusalem, 1967. 683 p.

DZUBIN, A., and COOCH, E.G. 1993. Measurements of geese: General field methods. Sacramento: California Waterfowl Association. 20 p.

EVANS, R.M. 1970. Oldsquaws nesting in association with arctic terns at Churchill, Manitoba. Wilson Bulletin 82(4):383-390.

GREEN, R.E. 1989. Transformation of crude proportions of nests that are successful for comparison with Mayfield estimates of nest success. Ibis 131:305-306.

HANSON, H.C., SCOTT, P., and QUENEAU, P. 1956. The geography, birds and mammals of the Perry River region. Arctic Institute of North America Special Publication 3.

JOHNSGARD, P.A. 1975. Waterfowl of North America. Bloomington: Indiana University Press.

1978. Ducks, geese, and swans of the world. Lincoln: University of Nebraska Press.

JOHNSON, D.H. 1979. Estimating nest success: The Mayfield method and an alternative. Auk 96(4):651-661.

JOHNSON, S.K., and HERTER, D.R. 1989. The birds of the Beaufort Sea. Anchorage: BP Exploration Inc.

KRAPU, G.L., and REINECKE, K.J. 1992. Foraging ecology and nutrition. In: Batt, B.D.J., Afton, A.D., Anderson, M.G., Ankney, C.D., Johnson, D.H., Kadlec, J.A., and Krapu, G.L., eds. Ecology and management of breeding waterfowl. Minneapolis: University of Minnesota Press. 1-29.

LAMOTHE, P. 1973. Biology of the king eider (Somateria spectabilis) in a fresh water breeding area on Bathurst Island, N.W.T. M.Sc. Thesis, University of Alberta, Edmonton, Alberta. $125 \mathrm{p}$.

LARSON, S. 1960. On the influence of the arctic fox Alopex lagopus on the distribution of arctic birds. Oikos 11(2):276305.

LEBRETON, J.D., BURNHAM, K.P., CLOBERT, J., and ANDERSON, D.R. 1992. Modeling survival and testing biological hypotheses using marked animals: A unified approach with case studies. Ecological Monographs 62:67-118.

MacDONALD, S.D. 1954. Report on biological investigations at Mould Bay, Prince Patrick Island, N.W.T., in 1952. Annual Report of the National Museum of Canada 132. 214-238.

MANNING, T.H., and MACPHERSON, E.O. 1961. A biological investigation of Prince of Wales Island, N.W.T. Transactions of the Royal Canadian Institute No. 33. 116-239.
MANNING, T.H., HOHN, E.O., and MACPHERSON, A.H. 1956. The birds of Banks Island. National Museum of Canada Bulletin 143. $144 \mathrm{p}$

MAYFIELD, H.F. 1975. Suggestions for calculating nest success. Wilson Bulletin 87(4):456-466.

McLANDRESS, M.R. 1983. Temporal changes in habitat selection and nest spacing in a colony of Ross' and lesser snow geese. Auk 100:335-343.

PALMER, R.S. 1975. Handbook of North American birds, Vol. 3. Waterfowl (Part 2). New Haven: Yale University Press.

- 1977. King eider studies. British Birds 70:107-113.

PARMELEE, D.F., STEPHENS, H.A., and SCHMIDT, R.H. 1967. The birds of southeastern Victoria Island and adjacent small islands. National Museum of Canada Bulletin 222. 229 p.

QUINLAN, S.E., and LEHNHAUSEN, W.A. 1982. Arctic fox, Alopex lagopus, predation on nesting common eiders, Somateria mollissima, at Icy Cape, Alaska. Canadian Field-Naturalist 96(4):462-466.

ROBERTSON, G.J. 1995. Factors affecting nest site selection and nesting success in the common eider Somateria mollissima. Ibis 137:109-115.

RYDER, J.P. 1972a. Timing and spacing of nests and breeding biology of Ross' goose. Unpubl. Ph.D. Thesis, University of Saskatchewan, Saskatoon. 213 p.

\section{5.}

SAS INSTITUTE, INC. 1990. User's guide, version 6. Cary, North Carolina. 846 p.

SCHMUTZ, J.K., ROBERTSON, R.J., and COOKE, F. 1983. Colonial nesting of the Hudson Bay eider duck. Canadian Journal of Zoology 61:2424-2433.

SLATTERY, S.M. 1994. Neonate reserves, growth and survival of Ross' and lesser snow goose goslings. M.Sc. Thesis, University of Saskatchewan, Saskatoon. 111 p.

SOPER, J.D. 1928. A faunal investigation of southern Baffin Island. National Museum of Canada Bulletin 53. 143 p.

SUMMERS, R.W., UNDERHILL, L.G., SYROECHKOVSKI, E.E., Jr., LAPPO, H.G., PRYS-JONES, R.P., and KARPOV, V. 1994. The breeding biology of dark-bellied brent geese Branta $b$. bernicla and king eiders Somateria spectabilis on the northeastern Taimyr Peninsula, especially in relation to snowy owl Nyctea scandiaca nests. Wildfowl 45:110-118.

THOMPSON, D.Q., and PERSON, R.A. 1963. The eider pass at Point Barrow, Alaska. Journal of Wildlife Management 27: 348-356.

WELLER, M.W. 1956. A simple field candler for waterfowl eggs. Journal of Wildlife Management 20:111-113.

WOODBY, D.A., and DIVOKY, G.J. 1982. Spring migration of eiders and other waterbirds at Point Barrow, Alaska. Arctic 35(3):403-410.

YOUNG, A.D., and TITMAN, R.D. 1986. Costs and benefits to red-breasted mergansers nesting in tern and gull colonies. Canadian Journal of Zoology 64:2339-2343. 